\title{
Immigration and venereal disease in England and Wales*
}

\author{
R. R. WILLCOX† \\ St. Mary's Hospital, London, and King Edward VII Hospital, Windsor
}

It is traditional to blame the spread of venereal diseases on immigrants as the theories on the early dissemination of syphilis in Europe and elsewhere bear witness. Nevertheless, male immigrants, removed as they are from the restraining influences of the home and of normal female partners, are certainly more prone to contract these infections than are those of the same age group in the host country; many world-wide examples can be cited in support.

In Great Britain it was estimated a few years ago that in England and Wales the West Indians of both sexes had an annual gonorrhoea rate 19 times as high as persons of the same age group in the home population (Willcox 1966a). Only a small percentage of this group knew the source of their infection (Willcox, Jefferiss, and Naughten, 1966).

\section{Numbers of immigrants in Great Britain}

The present paper assesses recent trends in the prevalence of venereal diseases in England and Wales and the contribution made by immigrants. Such a task would be easier if the numbers of immigrants were known precisely but accurate figures are impossible to obtain. Some groups, e.g. the Irish, the Armed Forces and those working permanently on ships and aircraft are not recorded, but the data for others are compiled annually by the Home Office and published by H.M. Stationery Office under the title 'Commonwealth Immigrants Act 1962 Control of Immigration - Statistics' (Table I : see also Fig. 1a).

The net numbers of immigrants since 1955 had risen sharply by 1961 and 1962 when the Commonwealth Immigrants Act was passed, since when the net total numbers have decreased from 136,400 in 1961 to 38,498 in 1968 .

The figures for West Indians reached a peak of 66,300 in 1961 , but have since markedly fallen; by 1966 , although there was a net gain of 9,620 , the immigrants were mainly children and there was in

^Paper presented at a Symposium 'The Doctor and the Immigrant', at Dudley Road Hospital, Birmingham, on January 24, 1970

tMember of the WHO Expert Panel on Venereal Diseases and Treponematoses
TABLE I Estimated net inward movement of Commonwealth citizens

\begin{tabular}{|c|c|c|c|c|}
\hline Year & West Indians & $\begin{array}{l}\text { Indians and } \\
\text { Pakistanis }\end{array}$ & All Others & Totals \\
\hline 1955 & $\begin{array}{l}27,550 \\
29,800\end{array}$ & $\begin{array}{l}7,650 \\
7650\end{array}$ & 7,500 & 42,700 \\
\hline 1956 & 29,800 & 7,650 & 7,600 & 45,050 \\
\hline 1957 & 23,000 & 11,800 & 7,600 & 42,400 \\
\hline 1958 & 15,000 & 10,900 & 3,950 & 29,850 \\
\hline 1959 & 16,400 & 3,800 & 1,400 & 21,600 \\
\hline 1960 & 49,650 & 8,400 & -350 & 57,700 \\
\hline 1961 & 66,300 & 48,850 & 21,250 & 136,400 \\
\hline 1962 & 35,040 & 44,040 & 18,320 & 97,400 \\
\hline 1963 & 7,928 & $33,834^{4}$ & 24,238 & 66,000 \\
\hline 1964 & 14,848 & 26,493 & 34,158 & 75,499 \\
\hline 1965 & 13,400 & 26,242 & 24,177 & 63,819 \\
\hline 1966 & $9,620^{1}$ & 26,410 & 15,318 & 51,348 \\
\hline 1967 & $10,080^{2}$ & $43,814^{6}$ & $-17,526^{7}$ & 36,368 \\
\hline 1968 & $4,799^{3}$ & $43,216^{6}$ & $-9,517^{8}$ & 38,498 \\
\hline
\end{tabular}

Figures for 1955-1962 are approximated

1. A negative balance of 467 adult men but a positive balance of 692 adult women

2. All children, as there was a negative balance of 1,376 adults

3. All children, as there was a negative balance of 341 adults

4. $17 \cdot 1$ per cent. children

5. $43 \cdot 3$ per cent. children

6. 46.3 per cent. children

7. Negative balance from loss of 28,269 Australians, Canadians and New Zealanders

8. Negative balance from loss of 28,075 Australians, Canadians, and New Zealanders, only $3 \cdot 2$ per cent. of whom were children

fact a small net loss of adult men. In 1967-1968, when the gain was 14,879 , this was entirely accounted for by children, and there was a net loss of 1,717 adults during these 2 years.

Indian and Pakistani immigrants also reached peak figures in 1961 with 48,850 gains, but after a subsequent small fall the numbers have again increased and a gain of 87,030 was recorded in the two years 1967-1968. However, 43.3 to 46.3 per cent. of these were children, the proportion of whom had risen from $17 \cdot 1$ per cent. in 1963, and this means that the numbers of adults have declined.

The gains for all other groups reached a peak in 1964 , with 34,158 more admissions than exits, and these numbers showed a negative balance of 27,043 in 1967-1968; this state of affairs was due to a much larger loss of 56,344 citizens from Canada, Australia, and New Zealand during this time (only $3 \cdot 2$ per cent. 


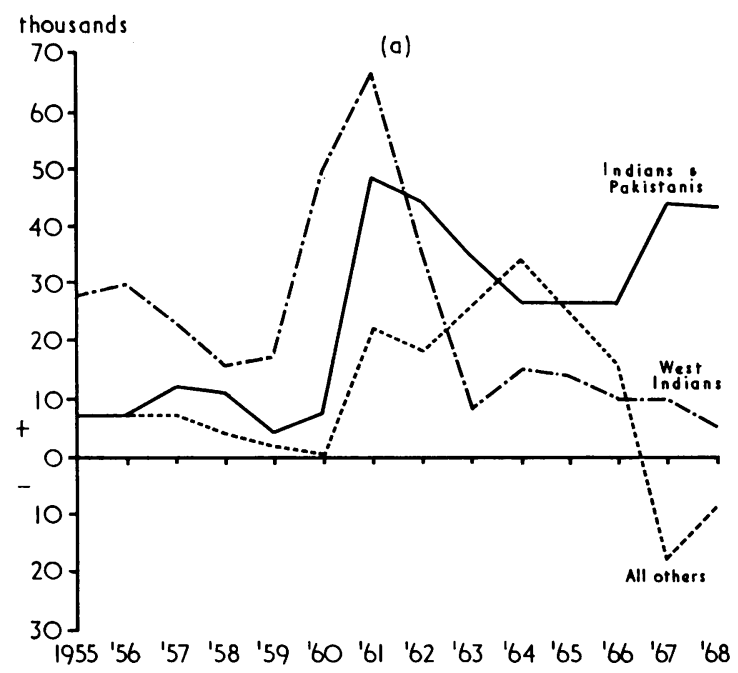

FIG. 1(a) Net inward gain of Commonwealth citizens, 1955 to 68 (in thousands)

of whom were children in 1968) (Fig. 1b), and if these are discounted there was an appreciable gain of 29,291 immigrants of other groups.

\section{Country of origin of patients with venereal disease}

SOURCE OF INFORMATION

Information concerning the country of origin of patients with gonorrhoea is available from the numerous studies of the British Cooperative Clinical Group covering the years 1952, 1955, and 1958 (British Cooperative Clinical Group, 1960) and annually since 1960 - since when a coverage of 81 to 96 per cent. of the national totals of infections in both sexes has been obtained (British Cooperative Clinical Group, 1960; 1962; 1963a; 1963b; 1965a; 1965b; 1967a; 1968a; 1968b; 1970a). From these figures it is possible to make reasonably accurate estimates of the total numbers of clinic cases arising in different ethnic groups over a period of 16 years. The situation up to 1964 has been reviewed previously (Willcox, 1966a, 1966b).

Similar information regarding primary and secondary syphilis is available only since 1964 (British Cooperative Clinical Group, 1965c; 1967b; 1968c; $1968 \mathrm{~d} ; 1970 \mathrm{~b})$. More than 90 per cent. coverage was obtained in most of these studies and similar calculations have been made from these data but, as with g.jnorrhoea, only the figures for England and Wales have been selected.

No national data have been compiled for nontonococcal urethritis or for other conditions, but local clinic experience would indicate that the pattern

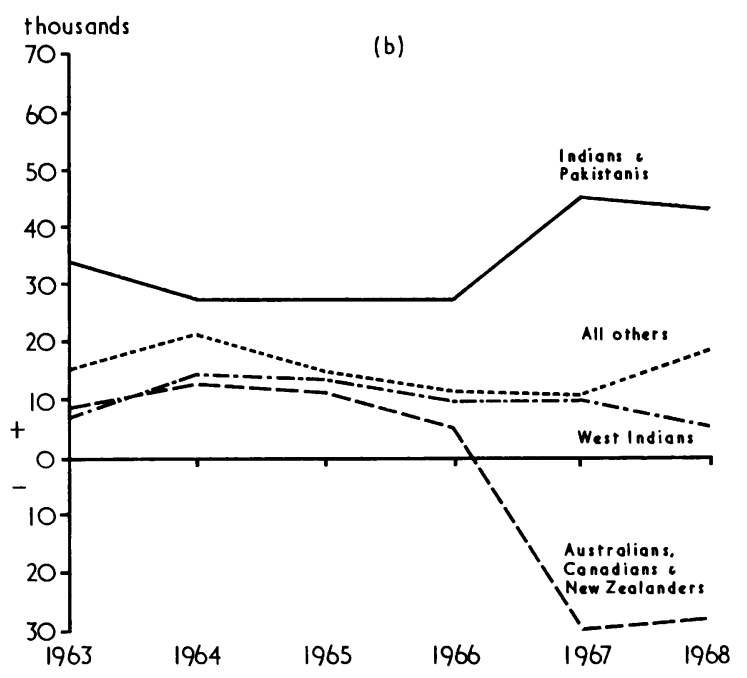

FIG. 1(b) Gains and losses of Commonwealth citizens, 1963 to 68 (in thousands)

for non-gonococcal urethritis may resemble that of gonorrhoea.

\section{LATEST AVAILABLE FIGURES}

The data for the year 1968 are shown (overleaf) in Table II and Fig. 2 (British Cooperative Clinical Group, 1970a; 1970b).

In 1968 immigrants accounted for $42 \cdot 1$ per cent. of male patients with gonorrhoea but only $17 \cdot 3$ per cent. of female patients. They also accounted for 35.0 per cent. of males with primary and secondary syphilis but only 20.3 per cent. of females.

These figures mean relatively little in themselves and have to be considered in relation to the trends which have been observed over previous years.

\section{Gonorrhoea}

TRENDS IN NATIONAL STATISTICS

The total numbers of new cases of gonorrhoea recorded in the clinics of England and Wales are shown (overleaf) in Table III and Fig. 3, which also indicate the trends and peak figures in each sex since the end of the second world war.

\section{Males}

The figures for males reached an all-time peak of 36,912 cases in 1946 ; this had fallen by 59.4 per cent. in 1951 , and later by 62.2 per cent. to a nadir of 13,962 cases in 1954. Between 1952, the year the Cooperative Clinical Group Studies began, and 1955, there was continued overall but small decline representing an annual decrease of 3.1 per cent. Between 1955 and 1961 there occurred an explosive rise averaging no less than 18.3 per cent. per year. This 
TABLE II Venereal disease in immigrants and others, 1968 (percentages)

\begin{tabular}{|c|c|c|c|c|}
\hline \multirow{2}{*}{ Race } & \multicolumn{2}{|c|}{ Gonorrhoea } & \multicolumn{2}{|c|}{$\begin{array}{l}\text { Primary and } \\
\text { secondary syphilis }\end{array}$} \\
\hline & Males & Females & Males & Females \\
\hline $\begin{array}{l}\text { West Indians } \\
\text { Other immigrants } \\
\text { U.K.-born }\end{array}$ & $\begin{array}{l}17 \cdot 2 \\
24 \cdot 9 \\
57 \cdot 8\end{array}$ & $\begin{array}{r}6 \cdot 9 \\
10 \cdot 4 \\
82 \cdot 7\end{array}$ & $\begin{array}{r}8 \cdot 8 \\
26 \cdot 2 \\
65 \cdot 0\end{array}$ & $\begin{array}{r}8 \cdot 4 \\
11 \cdot 9 \\
79 \cdot 7\end{array}$ \\
\hline Total & $100 \cdot 0$ & $100 \cdot 0$ & $100 \cdot 0$ & $100 \cdot 0$ \\
\hline
\end{tabular}

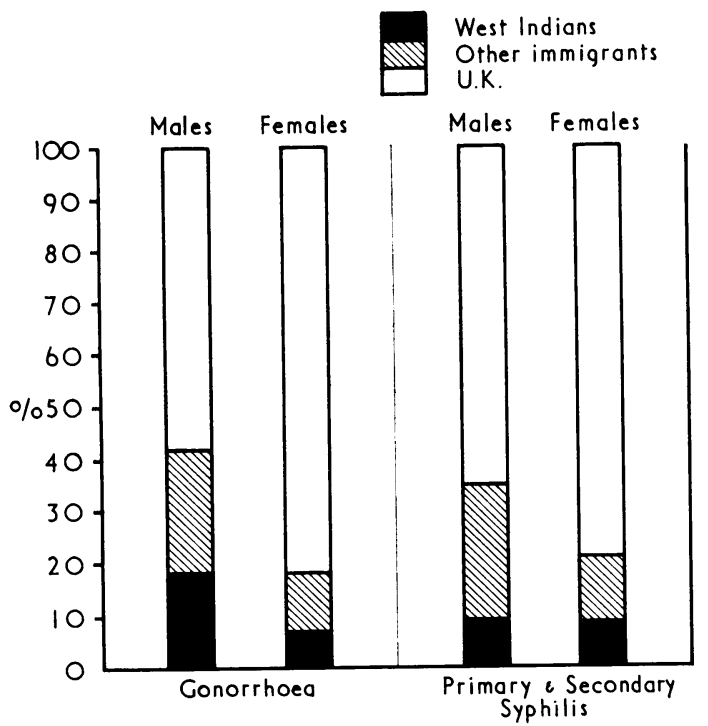

FIG. 2 Percentage distribution of venereal disease in immigrants and others, 1968, by sex

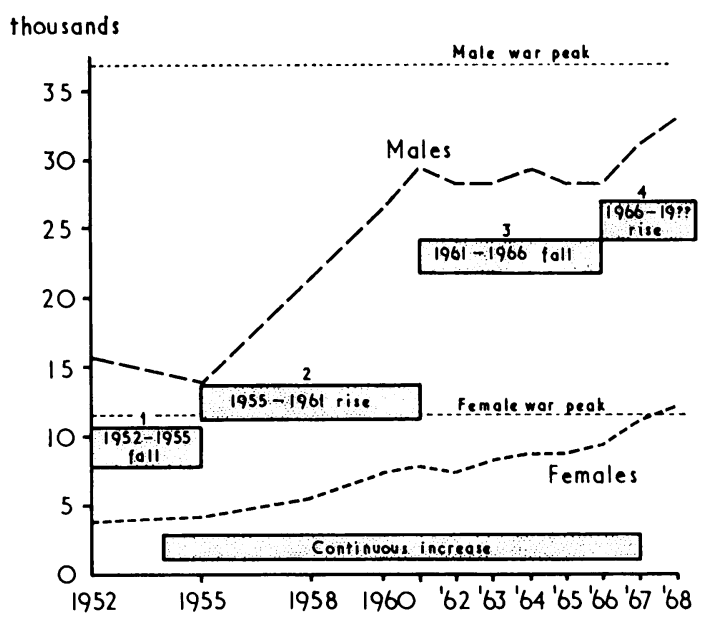

FI G. 3 New cases of gonorrhoea in the clinics of England and Wales, 1952 to 68, by sex (in thousands)

was checked and indeed partially reversed in the years 1961 to 1966 , when there was an average annual fall of 1.1 per cent. A second marked rise was seen between 1966 and 1968, with a substantial average annual increase of 8.4 per cent., and it seems likely that the end of this wave is not yet in sight.

\section{Females}

The figures for females showed a larger fall of 73.4 per cent. from the all-time peak of 11,603 cases in 1945 to a nadir of 3,089 cases in 1951 , but there has since been a continuous though varying increase. In

TABLE III Number of cases of gonorrhoea in the clinics of England and Wales (Ministry of Health, 1968)

\begin{tabular}{|c|c|c|c|c|}
\hline \multirow{2}{*}{ Year } & \multicolumn{2}{|l|}{ Males } & \multicolumn{2}{|l|}{ Females } \\
\hline & No. of cases & Trend & No. of cases & Trend \\
\hline $\begin{array}{l}1945 \\
1946 \\
1951\end{array}$ & $\begin{array}{l}21,280 \\
36,912 \\
14,975\end{array}$ & $\begin{array}{l}1946-1951 \\
\text { FALL of } 59 \cdot 4 \text { per cent. } \\
(62 \cdot 2 \text { per cent. by } 1954)\end{array}$ & $\begin{array}{r}11,603 \\
10,431 \\
3,089\end{array}$ & $\begin{array}{l}1945-1951 \\
\text { FALL of } 73.4 \text { per cent. }\end{array}$ \\
\hline $\begin{array}{l}1952 \\
1955\end{array}$ & $\begin{array}{l}15,510 \\
14,079\end{array}$ & $\begin{array}{l}\text { 1952-1955 } \\
\text { FALL of } 9 \cdot 2 \text { per cent. }\end{array}$ & $\begin{array}{l}3,585 \\
3,766\end{array}$ & $\begin{array}{l}1952-1955 \\
\text { RISE of } 5 \cdot 0 \text { per cent. }\end{array}$ \\
\hline $\begin{array}{l}1955 \\
1958 \\
1960 \\
1961\end{array}$ & $\begin{array}{l}14,079 \\
22,398 \\
26,618 \\
29,519\end{array}$ & $\begin{array}{l}\text { 1955-1961 } \\
\text { RISE of } 109 \cdot 7 \text { per cent. }\end{array}$ & $\begin{array}{l}3,766 \\
5,489 \\
7,152 \\
7,588\end{array}$ & $\begin{array}{l}1955-1961 \\
\text { RISE of } 101.5 \text { per cent. }\end{array}$ \\
\hline $\begin{array}{l}1961 \\
1962 \\
1963 \\
1964 \\
1965 \\
1966\end{array}$ & $\begin{array}{l}29,519 \\
28,329 \\
27,895 \\
29,050 \\
27,886 \\
27,921\end{array}$ & $\begin{array}{l}1961-1966 \\
\text { FALII. of } 5.4 \text { per cent. }\end{array}$ & $\begin{array}{l}7,588 \\
7,109 \\
8,154 \\
8,615 \\
8,805 \\
9,562\end{array}$ & $\begin{array}{l}1961-1966 \\
\text { RISE of } 26.0 \text { per cent. }\end{array}$ \\
\hline $\begin{array}{l}1966 \\
1967 \\
1968\end{array}$ & $\begin{array}{l}27,921 \\
30,645 \\
32,595\end{array}$ & $\begin{array}{l}1966-1968 \\
R I S E \text { of } 16.7 \text { per cent. } \\
\text { Now } 88.3 \text { per cent. of post-war peak }\end{array}$ & $\begin{array}{r}9,562 \\
11,184 \\
12,367\end{array}$ & $\begin{array}{l}1966-1968 \\
R I S E \text { of } 29 \cdot 3 \text { per cent. } \\
\text { Now } 106.6 \text { per cent. of post-war peak }\end{array}$ \\
\hline
\end{tabular}


the years 1952 to 1955, when the male cases fell annually by 3.1 per cent., the increase in female cases was only slight (an average of 1.7 per cent. per year), but the numbers rose drastically between 1955 and 1961, with an average annual increase as high as 16.9 per cent. The rising trend continued more slowly from 1961 to 1966, with a smaller annual increase, of 5.2 per cent., while male figures were falling; but as with males a further marked increase occurred between 1966 and 1968, with an average annual increase of 14.7 per cent.

Thus, the credit balance of case reduction which followed the introduction of antibiotic therapy is already virtually dissipated. The number of infections in men now stands at 88.3 per cent. of the post-war peak incidence while that in females, at 106.6 per cent., already shows an 'overdraft'.

\section{GONORRHOEA IN IMMIGRANT AND OTHER MALES}

Estimated numbers and trends

Estimated numbers of cases of gonorrhoea in West Indians, in other immigrants and in U.K.-born persons are given in Table IV (Fig. 4).

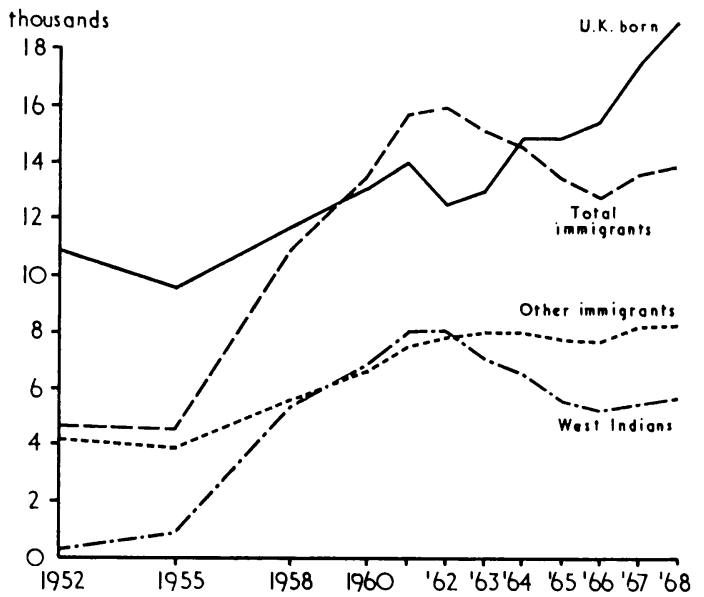

FIG. 4 Estimated numbers of cases of gonorrhoea in West Indian, other immigrant, and U.K.-born males, 1952 to 68 (in thousands)
There is a general rising trend in persons born in the United Kingdom. Between 1955 and 1961 the figures for West Indians rose explosively and for a few years the number of infections in this group alone exceeded those in all other immigrant groups, but since 1962 the numbers of West Indians with gonorrhoea have fallen substantially (although there has been a recent slight recrudescence) while during the past 7 years the figures for other immigrants have remained relatively static.

In the earlier years the numbers of infections in those born in the United Kingdom substantially exceeded the total of all immigrant infections, but between 1955 and 1961 the figures became almost equal. Later, between 1961 and 1963, the figures for all infections in immigrants exceeded those in U.K.born persons. Since 1964, the contribution from U.K.-born patients has exceeded the total of all immigrant patients.

The estimated figures for other immigrants are further broken down (overleaf) in Table V (Fig. 5). These show the Asians to have emerged as the second most prominent group and since 1960 to have been well ahead of the other groups. Recently, however, their numbers have fallen while those of certain other groups, e.g. the Europeans and the Irish, have increased. In 1968 the numbers of Europeans involved were still less than they had been in 1952 .

\section{Contribution of immigrants to changing trends}

Table VI and Fig. 6 (overleaf) give average annual differences and proportion of West Indians, other immigrants, and those born in the United Kingdom during the four periods since 1952 when differences in overall trends were observed.

During the 3-year period, 1952-1955, the average annual fall of $3 \cdot 1$ per cent. was entirely accounted for by a decline in infections in the U.K.-born and in other immigrants; the West Indians were already showing the beginning of their subsequent substantial contribution. During this time, 93.4 per cent. of the decrease was associated with infections in the U.K.born and only 6.6 per cent. with those in immigrant groups as a whole.

TABLE IV Estimated numbers of cases of gonorrhoea in West Indians, other immigrants, and U.K.-born males (England and Wales)

\begin{tabular}{|c|c|c|c|c|c|c|c|c|c|c|c|c|}
\hline Year & 1952 & 1955 & 1958 & 1960 & 1961 & 1962 & 1963 & 1964 & 1965 & 1966 & 1967 & 1968 \\
\hline $\begin{array}{l}\text { West Indians } \\
\text { Other immigrants } \\
\text { (Total immigrants) } \\
\text { U.K.-born }\end{array}$ & $\begin{array}{c}465 \\
4,234 \\
(4,699) \\
10,811\end{array}$ & $\begin{array}{c}845 \\
3,759 \\
(4,604) \\
9,475\end{array}$ & $\begin{array}{c}5,315 \\
5,488 \\
(10,863) \\
11,535\end{array}$ & $\begin{array}{c}6,788 \\
6,654 \\
(13,442) \\
13,176\end{array}$ & $\begin{array}{c}8,059 \\
7,527 \\
(15,586) \\
13,933\end{array}$ & $\begin{array}{c}8,017 \\
7,847 \\
(15,864) \\
12,465\end{array}$ & $\begin{array}{c}7,029 \\
7,950 \\
(14,979) \\
12,916\end{array}$ & $\begin{array}{c}6,536 \\
7,873 \\
(14,409) \\
14,641\end{array}$ & $\begin{array}{c}5,577 \\
7,586 \\
(13,163) \\
14,723\end{array}$ & $\begin{array}{c}5,125 \\
7,554 \\
(12,679) \\
15,242\end{array}$ & $\begin{array}{c}5,304 \\
8,052 \\
(13,356) \\
17,289\end{array}$ & $\begin{array}{c}5,614 \\
8,143 \\
(13,757) \\
18,838\end{array}$ \\
\hline Totals & 15,510 & 14,079 & 22,398 & 26,618 & 29,519 & 28,329 & 27,895 & 29,050 & 27,886 & 27,921 & 30,645 & 32,595 \\
\hline
\end{tabular}




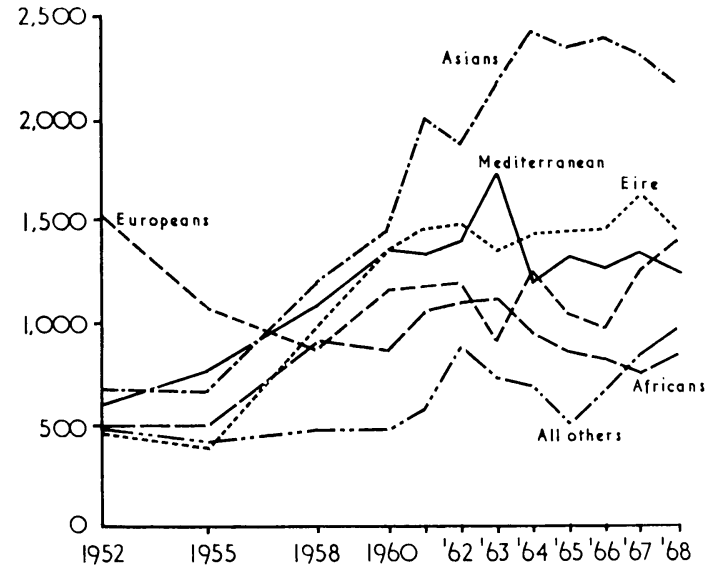

FIG. 5 Estimated numbers of cases of gonorrhoea in male immigrants other than West Indians, 1952 to 68

During the following 6-year period, 1955-1961, there was an explosive average annual increase of 18.3 per cent. This was due to increases in all groups but mainly in immigrants (71 per cent.), the U.K.born being responsible for only 29 per cent. The West Indians accounted for no less than 46.7 per cent. of this increase.

During the 5 years $1961-1966$, there was a small average annual fall of $1 \cdot 1$ per cent. This was entirely accounted by for the declining numbers of West

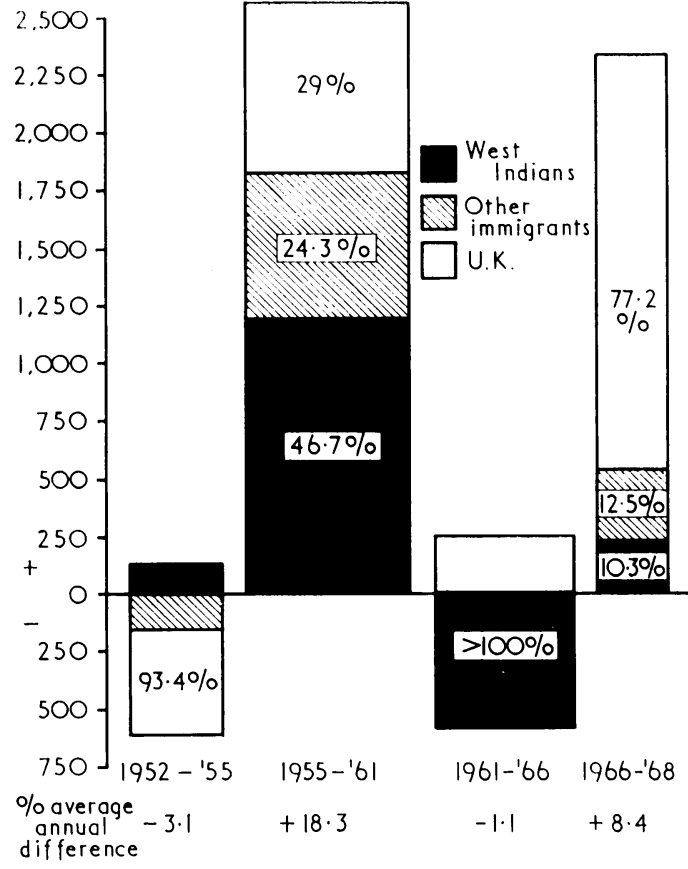

FIG. 6 Cases of gonorrhoea in West Indian, other immigrant, and U.K.-born males, showing percentage average annual differences in four periods : 1952 to 55, 1955 to 61, 1961 to 66, and 1966 to 68

TABLE $\mathrm{V}$ Estimated numbers of cases of gonorrhoea in immigrant males other than West Indians (England and Wales)

\begin{tabular}{|c|c|c|c|c|c|c|c|c|c|c|c|c|}
\hline Geographical place of origin & 1952 & 1955 & 1958 & 1960 & 1961 & 1962 & 1963 & 1964 & 1965 & 1966 & 1967 & 1968 \\
\hline Asia & 667 & 648 & 1,210 & 1,464 & 2,007 & 1,870 & 2,176 & 2,440 & 2,355 & 2,387 & 2,311 & 2,173 \\
\hline Mediterranean & 589 & 746 & 1,075 & 1,357 & 1,328 & 1,388 & 1,729 & 1,191 & 1,321 & 1,256 & 1,337 & 1,248 \\
\hline Eire & 450 & 380 & 986 & 1,357 & 1,446 & 1,473 & 1,339 & 1,424 & 1,438 & 1,450 & 1,607 & 1,533 \\
\hline Europe & 1,551 & 1,070 & 851 & 1,145 & 1,151 & 1,161 & 892 & 1,220 & 1,021 & 983 & 1,232 & 1,399 \\
\hline Africa & 496 & 507 & 896 & 852 & 1,033 & 1,077 & 1,088 & 930 & 849 & 813 & 742 & 824 \\
\hline All others & 481 & 408 & 470 & 479 & 562 & 878 & 726 & 668 & 602 & 665 & 823 & 966 \\
\hline Total & 4,234 & 3,759 & 5,488 & 6,654 & 7,527 & 7,847 & 7,950 & 7,873 & 7,586 & 7,554 & 8,052 & 8,143 \\
\hline
\end{tabular}

T ABLE VI Average annual differences in West Indian, other immigrant, and U.K.-born males

\begin{tabular}{|c|c|c|c|c|c|c|c|c|}
\hline \multirow[t]{2}{*}{ Period } & \multicolumn{2}{|c|}{$1952-1955$ ( 3 years) } & \multicolumn{2}{|c|}{ 1955-1961 (6 years) } & \multicolumn{2}{|c|}{ 1961-1966 (5 years) } & \multicolumn{2}{|c|}{ 1966-1968 (2 years) } \\
\hline & Difference & $\begin{array}{l}\text { Average } \\
\text { annual } \\
\text { difference }\end{array}$ & Difference & $\begin{array}{l}\text { Average } \\
\text { annual } \\
\text { difference }\end{array}$ & Difference & $\begin{array}{l}\text { Average } \\
\text { annual } \\
\text { difference }\end{array}$ & Difference & $\begin{array}{l}\text { Average } \\
\text { annual } \\
\text { difference }\end{array}$ \\
\hline West Indians & 380 & +126 & $\begin{array}{l}7,234 \\
(46 \cdot 7 \text { per cent.) }\end{array}$ & 1,206 & $-2,922$ & -584 & $\begin{array}{l}-480 \\
(10 \cdot 3 \text { per cent. })\end{array}$ & +240 \\
\hline $\begin{array}{l}\text { Other } \\
\text { immigrants }\end{array}$ & -475 & -158 & $\begin{array}{c}3,748 \\
(24 \cdot 3 \text { per cent. })\end{array}$ & +625 & -+12 & 2 & $\begin{array}{l}+588 \\
(12.5 \text { per cent. })\end{array}$ & +294 \\
\hline U.K.-born & $\begin{array}{l}-1,336 \\
\text { (93.4 per cent.) }\end{array}$ & -445 & $\begin{array}{l}4,458 \\
(29 \text { per cent. })\end{array}$ & $\because 743$ & 1,312 & +262 & $\begin{array}{l}3,606 \\
(77 \cdot 2 \text { per cent. })\end{array}$ & 1,804 \\
\hline Total & $\begin{array}{l}-1,431 \\
(100 \cdot 0 \text { per cent. })\end{array}$ & -477 & $\begin{array}{c}15,440 \\
(100 \cdot 0 \text { per cent. })\end{array}$ & $: 2,574$ & $-1,598$ & -320 & $\begin{array}{c}4,674 \\
(100 \cdot 0 \text { per cent. })\end{array}$ & 2,338 \\
\hline $\begin{array}{l}\text { Percentage } \\
\text { difference }\end{array}$ & $-9 \cdot 2$ & $-3 \cdot 1$ & $109 \cdot 7$ & 18.3 & $-5 \cdot 4$ & $-1 \cdot 1$ & $+16 \cdot 7$ & 8.4 \\
\hline
\end{tabular}


Indian patients, and was achieved in spite of a slight increase in patients born in the United Kingdom, the figures for other immigrants remaining virtually the same.

During the most recent period, 1966-1968, there has again been a substantial overall rise ( 8.4 per cent.) which has involved all three main groups. It is clear that this second upsurge, the full effects of which are not yet apparent, differs markedly from the first in so far as U.K.-born persons have been responsible for no less than 77.2 per cent. and immigrants for

FIG. 7 Estimated numbers of cases of gonorrhoea in female immigrants and other females, 1952 to 68 (in thousands)

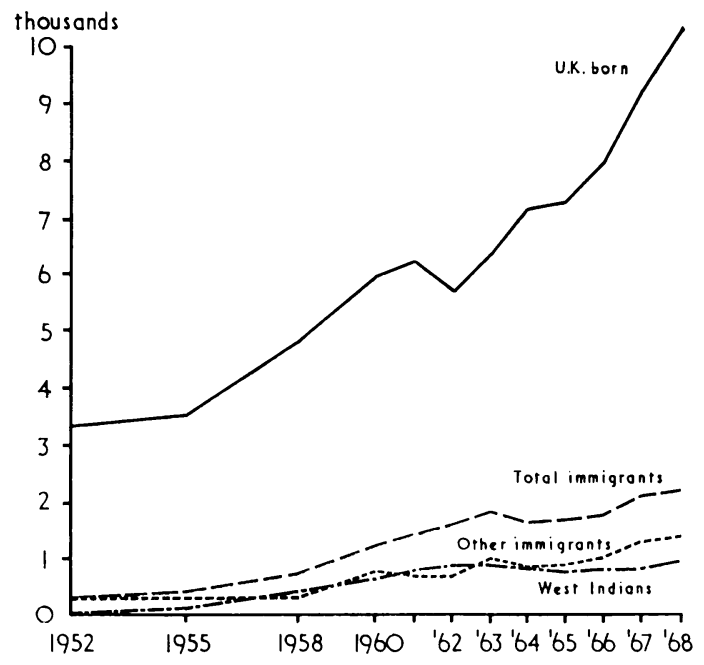

22.8 per cent., the West Indians contributing only 10.3 per cent.

FIG. 8 Cases of gonorrhoea in West Indian, other immigrant, and U.K.-born females, showing percentage average annual differences in four periods: 1952 to 55, 1955 to 61,1961 to 66 , and 1966 to 68

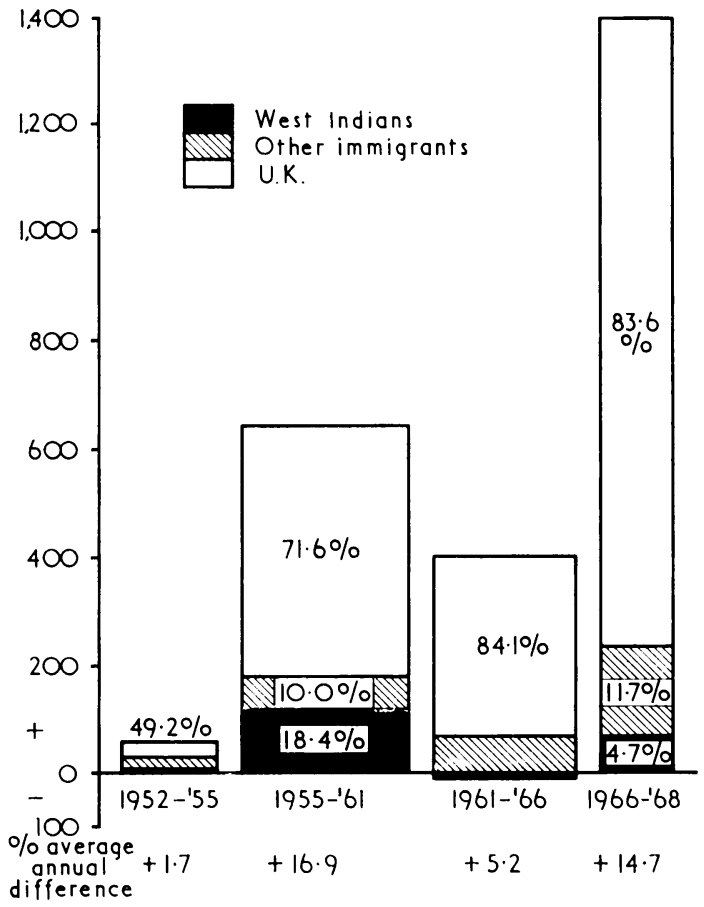

TABLE VII Estimated numbers of cases of gonorrhoea in immigrant and other females (England and Wales)

\begin{tabular}{|c|c|c|c|c|c|c|c|c|c|c|c|c|}
\hline Year & 1952 & 1955 & 1958 & 1960 & 1961 & 1962 & 1963 & 1964 & 1965 & 1966 & 1967 & 1968 \\
\hline $\begin{array}{l}\text { West Indians } \\
\text { Other immigrants } \\
\text { (Total immigrants) } \\
\text { U.K.-born }\end{array}$ & $\begin{array}{c}18 \\
172 \\
(190) \\
3,395\end{array}$ & $\begin{array}{c}41 \\
241 \\
(282) \\
3,484\end{array}$ & $\begin{array}{c}324 \\
296 \\
(620) \\
4,869\end{array}$ & $\begin{array}{c}565 \\
651 \\
(1,116) \\
5,936\end{array}$ & $\begin{array}{c}744 \\
622 \\
(1,366) \\
6,222\end{array}$ & $\begin{array}{c}832 \\
682 \\
(1,514) \\
5,595\end{array}$ & $\begin{array}{c}856 \\
946 \\
(1,792) \\
6,352\end{array}$ & $\begin{array}{c}741 \\
758 \\
(1,499) \\
7,116\end{array}$ & $\begin{array}{c}686 \\
827 \\
(1,513) \\
7,292\end{array}$ & $\begin{array}{c}720 \\
960 \\
(1,680) \\
7,882\end{array}$ & $\begin{array}{c}775 \\
1,222 \\
(1,997) \\
9,187\end{array}$ & $\begin{array}{c}853 \\
1,286 \\
(2,139) \\
10,228\end{array}$ \\
\hline Total & 3,585 & 3,766 & 5,489 & 7,152 & 7,588 & 7,109 & 8,154 & 8,615 & 8,805 & 9,562 & 11,184 & 12,367 \\
\hline
\end{tabular}

TABLE VIII Average annual differences in West Indian, other immigrant, and U.K.-born females

\begin{tabular}{|c|c|c|c|c|c|c|c|c|}
\hline \multirow[t]{2}{*}{ Period } & \multicolumn{2}{|c|}{$1952-1955$ (3 years) } & \multicolumn{2}{|c|}{ 1955-1961 (6 years) } & \multicolumn{2}{|c|}{ 1961-1966 (5 years) } & \multicolumn{2}{|c|}{ 1966-1968 (2 years) } \\
\hline & Difference & $\begin{array}{l}\text { Average } \\
\text { annual } \\
\text { difference }\end{array}$ & Difference & $\begin{array}{l}\text { Average } \\
\text { annual } \\
\text { difference }\end{array}$ & Difference & $\begin{array}{l}\text { Average } \\
\text { annual } \\
\text { difference }\end{array}$ & Difference & $\begin{array}{l}\text { Average } \\
\text { annual } \\
\text { difference }\end{array}$ \\
\hline West Indians & $\begin{array}{l}23 \\
(12 \cdot 7 \text { per cent.) }\end{array}$ & 8 & $\begin{array}{l}-: 703 \\
\text { (18.4 per cent.) }\end{array}$ & +117 & -24 & -5 & $\begin{array}{l}+133 \\
(4 \cdot 7 \text { per cent.) }\end{array}$ & +66 \\
\hline $\begin{array}{l}\text { Other } \\
\text { immigrants }\end{array}$ & $\begin{array}{l}\quad 69 \\
(38 \cdot 1 \text { per cent.) }\end{array}$ & +23 & $\begin{array}{l}+381^{1} \\
(10.0 \text { per cent. })\end{array}$ & +64 & +337 & +67 & $\begin{array}{c}\quad 327 \\
\text { (11.7 per cent.) }\end{array}$ & +163 \\
\hline U.K.-born & 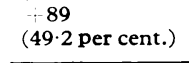 & 29 & $\begin{array}{l}2,738 \\
(71.6 \text { per cent.) }\end{array}$ & +456 & $\begin{array}{l}1,661 \\
(84 \cdot 1 \text { per cent.) }\end{array}$ & -332 & $\begin{array}{l}2,345 \\
\text { (83.6 per cent.) }\end{array}$ & $+1,173$ \\
\hline Total & $\begin{array}{l}181 \\
(100 \cdot 0 \text { per cent. })\end{array}$ & +60 & $\begin{array}{l}-3,822 \\
\text { (100.0 per cent.) }\end{array}$ & $\therefore 637$ & $\therefore 1,974$ & 394 & 2,805 & 1,402 \\
\hline $\begin{array}{l}\text { Percentage } \\
\text { difference }\end{array}$ & 5.0 & $+1 \cdot 7$ & $-101 \cdot 7$ & 16.9 & 26.0 & $5 \cdot 2$ & $29 \cdot 3$ & 14.7 \\
\hline
\end{tabular}


GONORRHOEA IN IMMIGRANT AND OTHER FEMALES

Estimated numbers and trends

The estimated figures for gonorrhoea in females in England and Wales are shown in Table VII and Fig. 7). These show that immigrant women make a relatively insignificant contribution to the numbers of cases of gonorrhoea in females. The major contribution comes from U.K.-born females, in whom the numbers of infections have shown a steady rise, broken only in 1962. The numbers of infections in immigrants rose noticeably between 1952 and 1963, fell between 1963 and 1965 and have risen again during the past 3 years. The recent rise in cases of gonorrhoea in immigrant women is less steep than that in women born in the United Kingdom.

\section{Contribution of immigrants to changing trends}

Table VIII and Fig. 8 show the average annual differences and relative proportions of West Indians, other immigrants and U.K.-born women during the four periods since 1952 when differences in the trends were observed in the figures for men.

During the first period, 1952-1955, when the males showed an average annual fall of 3.1 per cent., the females showed a small annual rise of 1.7 per cent. Only 49.2 per cent. of this rise was accounted for by U.K.-born females with 12.7 per cent. by West Indian females and 38.1 per cent. by other immigrant females.

During the second period, 1955-1961, while the male figures rose sharply (average annual rise 18.3 per cent.), the female figures rose in a comparable manner (average annual rise 16.9 per cent.). No less than 71.6 per cent. of the increase was accounted for by women born in the United Kingdom, 18.4 per cent. being attributable to West Indians and 10.0 per cent. to other immigrants.

During the third period, 1961-1966, while the male figures showed a small average annual decrease of 1.1 per cent., the female figures continued to rise but at a slower rate than before, averaging 5.2 per cent. per annum. The U.K.-born females were now responsible for 84.1 per cent. of this increase and immigrants for only 16.9 per cent.; this figure was more than accounted for by other immigrants as the numbers of infections in West Indians showed a slight decrease.

From 1966 to 1968 the rate of increase in females accelerated once more to an average of 14.7 per cent. per year (while the males had an average annual increase of only 8.4 per cent.). As with males the bulk of the increase was due to females born in the United Kingdom (83.6 per cent.), only 16.4 per cent. being due to immigrants $(4.7$ per cent. to West Indians and 11.7 per cent. to other immigrants).

\section{Primary and secondary syphilis}

TRENDS IN NATIONAL STATISTICS

After the second world war the figures for early syphilis (primary, secondary, and early latent in the first year of infection) fell even more dramatically than did those for gonorrhoea.

In males the post-war peak prevalence of 10,705 cases in 1946 was cut by 94.4 per cent. to 600 cases in 1954 and still further to 522 cases (a reduction of 95.1 per cent.) by 1958 . By 1964 , however, the total had increased to 1,422 , and by 1965 to 1,734 (Ministry of Health, 1968), 13.3 per cent. of the post-war peak.

In females the peak figure of 6,970 in 1946 was cut by 97.0 per cent. to 208 cases by 1954 and by 97.4 per cent. to 182 cases in 1958 . These numbers then increased slightly and in 1966 there were 388 cases, 5.6 per cent. of the post-war peak.

In recent years it has been considered more desirable to define early syphilis in terms of primary and secondary cases, omitting the early latent cases which have few and sometimes uncertain criteria for diagnosis.

\section{TRENDS IN IMMIGRANTS AND OTHER MALES}

British Cooperative Clinical Group studies on primary and secondary syphilis have been carried out only for the 5-year period 1964 to 1968 . During this time the male figures have remained fairly stable. The estimated numbers in the various racial groups are shown in Table IX (Fig. 9).

TABLE IX Estimated number of cases of primary and secondary syphilis in immigrant and other male groups

\begin{tabular}{|c|c|c|c|c|c|c|}
\hline \multirow{2}{*}{ Year } & \multirow{2}{*}{1964} & \multirow{2}{*}{1965} & \multirow{2}{*}{1966} & \multirow{2}{*}{1967} & \multicolumn{2}{|l|}{1968} \\
\hline & & & & & No. & Per cent. \\
\hline $\begin{array}{l}\text { U.K.-born } \\
\text { Asians } \\
\text { All other }\end{array}$ & $\begin{array}{l}717 \\
122\end{array}$ & $\begin{array}{l}801 \\
280\end{array}$ & $\begin{array}{l}569 \\
208\end{array}$ & $\begin{array}{l}655 \\
109\end{array}$ & $\begin{array}{r}705 \\
67\end{array}$ & $\begin{array}{r}65 \cdot 0 \\
6 \cdot 2\end{array}$ \\
\hline $\begin{array}{l}\text { immigrants } \\
\text { Europeans } \\
\text { West Indians }\end{array}$ & $\begin{array}{r}166 \\
108 \\
70\end{array}$ & $\begin{array}{r}200 \\
118 \\
70\end{array}$ & $\begin{array}{r}167 \\
88 \\
99\end{array}$ & $\begin{array}{r}124 \\
87 \\
100\end{array}$ & $\begin{array}{r}120 \\
98 \\
95\end{array}$ & $\begin{array}{r}11 \cdot 0 \\
9 \cdot 0 \\
8 \cdot 8\end{array}$ \\
\hline Totals & 1,183 & 1,469 & 1,131 & 1,075 & 1,085 & $100 \cdot 0$ \\
\hline
\end{tabular}

hundreds

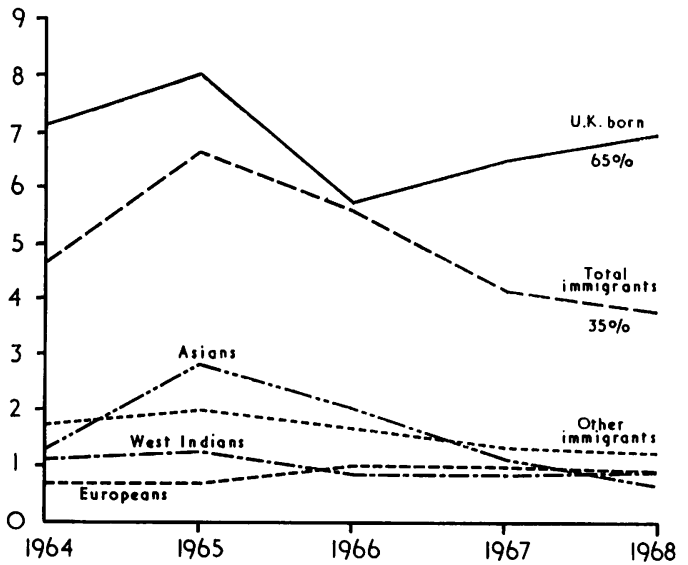

FIG. 9 Estimated numbers of cases of primary and secondary syphilis in male immigrants and other males, 1964 to 68 (in hundreds) 
Throughout this 5-year period the numbers of cases of primary and secondary syphilis in the indigenous population have exceeded those in all immigrants, whose cases comprised only 35 per cent. of the total in 1968, although in 1966 the numbers were about equal. The numbers of cases in U.K.born persons have been rising while those in immigrants have been declining.

Of the individual immigrant groups Asians were by far the most important between 1964 and 1967, but for the past 3 years cases in Asians have decreased and they are now fewer than those in West Indians and Europeans. The West Indian contribution to the numbers of cases of primary and secondary syphilis has been much less than to gonorrhoea.

\section{TRENDS IN IMMIGRANT AND OTHER FEMALES}

The estimated numbers of cases of primary and secondary syphilis in females are shown in Table $\mathrm{X}$ (Fig. 10).

TABLE X Estimated numbers of cases of primary and secondary syphilis in immigrant and other females

\begin{tabular}{|c|c|c|c|c|c|c|}
\hline \multirow{2}{*}{ Year } & \multirow{2}{*}{1964} & \multirow{2}{*}{1965} & \multirow{2}{*}{1966} & \multirow{2}{*}{1967} & \multicolumn{2}{|l|}{1968} \\
\hline & & & & & No. & Per cent. \\
\hline $\begin{array}{l}\text { West Indians } \\
\text { Other }\end{array}$ & 21 & 13 & 12 & 7 & 22 & $8 \cdot 4$ \\
\hline & 24 & 22 & 32 & 23 & 31 & 11.9 \\
\hline immigrants) & (45) & (35) & (44) & (30) & (53) & $(20 \cdot 3)$ \\
\hline U.K.-born & 167 & 238 & 198 & 216 & 205 & $79 \cdot 7$ \\
\hline Total & 212 & 273 & 242 & 246 & 258 & $100 \cdot 0$ \\
\hline
\end{tabular}

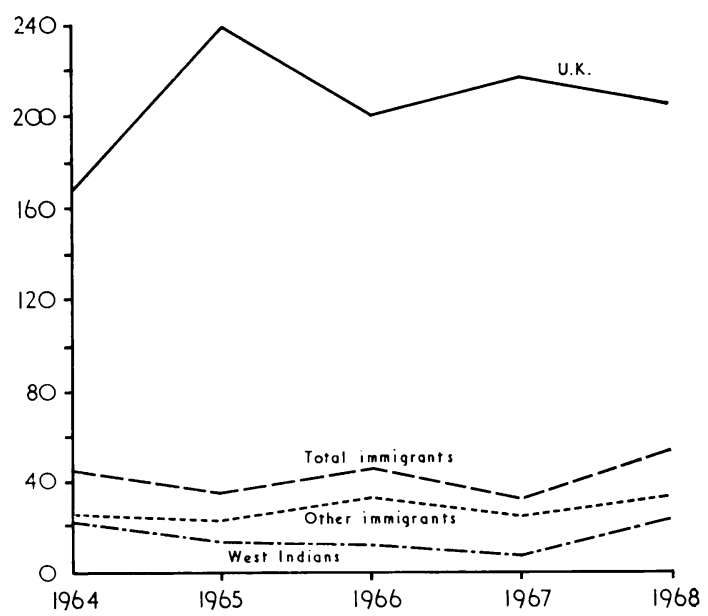

FIG. 10 Estimated numbers of cases of primary and secondary syphilis in female immigrants and other females, 1964 to 68

By far the greatest numbers of cases arise in women born in the United Kingdom (79.7 per cent. in 1968), although those in immigrants have risen somewhat during the past year. The latter increase is largely accounted for by a rise, after a fall, in the numbers of cases in West Indian women, who form the most prominent female immigrant group.

\section{Ratio of primary and secondary syphilis to gonorrhoea}

The annual ratios in males in the racial groups are shown in Table XI (Fig. 11). They have consistently been substantially higher in West Indians and Africans and also latterly in other Negro groups, and it is interesting to speculate on the reasons for this phenomenon. Possible explanations include a relative immunity to syphilis compared with gonorrhoea enjoyed by Negro groups on account of previous infections with yaws; a greater diversity of sexual partners used by these immigrants compared with the indigenous population, the latter probably having a greater number of more stable relationships (it has been suggested that gonorrhoea is more likely than syphilis to be acquired through a single exposure with an infected person - Marcussen, 1953); and the curative effect upon incubating syphilis of penicillin given for frequent gonococcal infections in the West Indians (Willcox, 1963).

TABLE XI Average annual ratio of gonorrhoea to syphilis. Numbers of cases of gonorrhoea in males to one of primary and secondary syphilis

\begin{tabular}{|c|c|c|c|c|c|}
\hline Year & 1964 & 1965 & 1966 & 1967 & 1968 \\
\hline Europeans & $11 \cdot 4$ & $8 \cdot 6$ & $11 \cdot 1$ & $13 \cdot 7$ & $13 \cdot 7$ \\
\hline U.K. and Eire & $20 \cdot 6$ & $18 \cdot 8$ & 26.9 & $21 \cdot 4$ & $26 \cdot 6$ \\
\hline Asia, Mediterranean, & & & & & \\
\hline and other non-Negro & $20 \cdot 8$ & $10 \cdot 0$ & $13 \cdot 7$ & $24 \cdot 3$ & $32 \cdot 3$ \\
\hline Other Negro & $31 \cdot 0$ & $28 \cdot 8$ & $23 \cdot 7$ & 23.6 & $57 \cdot 2$ \\
\hline Africans & $46 \cdot 3$ & $90 \cdot 8$ & $37 \cdot 0$ & 56.5 & $50 \cdot 3$ \\
\hline West Indians & 93.6 & $78 \cdot 8$ & $51 \cdot 6$ & $52 \cdot 1$ & $56 \cdot 4$ \\
\hline
\end{tabular}

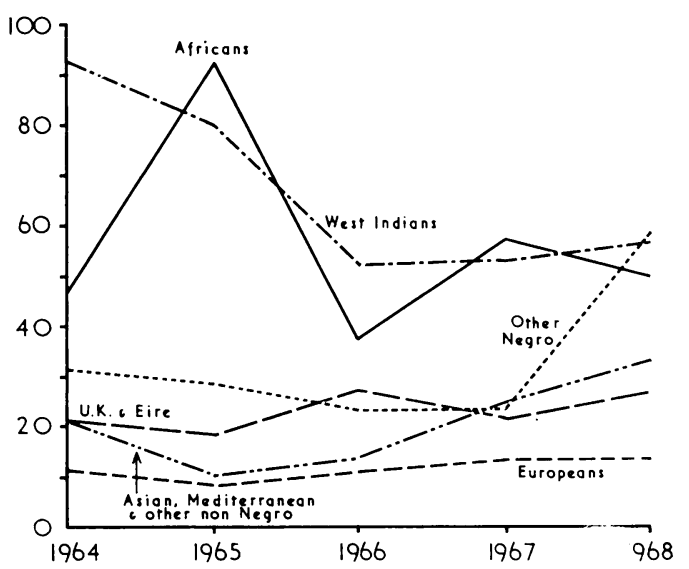

FIG. 11 Ratio of gonorrhoea to primary and secondary syphilis in male immigrants and other males, 1964 to 68 


\section{Importation of venereal disease}

Official figures for 1967 (Ministry of Health, 1968) indicate that 16.2 per cent. of infections with primary and secondary syphilis, the sources of which were known, were imported, compared to 4.3 per cent. for gonorrhoea. Higher rates of importation are to be expected in males than in females.

A study (British Cooperative Clinical Group, 1965d) relating the importation of primary and secondary syphilis to racial groups, showed that in the year in question 28.5 per cent. of infections were imported (16.0 per cent. by immigrants and 12.5 per cent. by U.K.-born persons) and that the other 71.5 per cent. were contracted in the United Kingdom (23.6 per cent. by immigrants and 47.9 per cent. by the home population). Of the total number of infections in U.K.-born persons 20.7 per cent. were imported, compared to 12.7 per cent. of those in the small number of West Indians, whereas with other immigrants the figure was as high as 45.0 per cent.

Of the imported cases no less than 43.8 per cent. were brought in by U.K.-born persons, 53.8 per cent. by other immigrants, and only 2.4 per cent. by West Indians.

Europeans and Africans with syphilis imported more infection than they acquired in Great Britain, Asians and those born in the Mediterranean region contracted slightly more disease here than they brought in with them, and most of the infections in both Irish and West Indians were acquired here.

No data are available concerning exports of infection.

\section{Sexual partners of immigrants}

RACIAL GROUPS

Another study of the consorts of male and female immigrants with gonorrhoea (British Cooperative Clinical Group, 1965e) has shown a general tendency in both sexes for like to consort with like (e.g. the male consorts of infected West Indian females were very largely West Indian and the female consorts of U.K.born males were almost exclusively U.K.-born). However, in this nation-wide study, it was not recorded whether the attending consorts were primary or secondary contacts, and it seems probable that many, often untraced, primary source contacts of immigrants are in fact girls born in the United Kingdom.

Data obtained in one study at St. Mary's Hospital, London, showed, for example, that no less than $79 \cdot 8$ per cent. of secondary contacts of West Indian males were West Indian, 7.9 per cent. were other immigrants, and only 12.3 per cent. were U.K.-born. On the other hand 57.9 per cent. of the source contacts of West Indians were U.K.-born, 24.3 per cent. were
West Indian, and $17 \cdot 8$ per cent. were other immigrants.

\section{AGE GROUPS}

Cooperative studies of the age groups of immigrant and other patients with gonorrhoea have shown that proportionately more teenage females with gonorrhoea were attending the clinics dealing with relatively few West Indian males, compared with the clinics where the bulk of West Indians were treated (Willcox, 1965a, 1966a). Indeed, the proportion of teenagers amongst the consorts of West Indians was smaller than for other groups, but this finding may well have been influenced by a higher proportion of the secondary contacts of West Indians being in the older age groups, and being more likely to attend the clinics.

Further data from St. Mary's hospital have shown that 49.4 per cent. of the secondary contacts of male West Indians were 25 years old and over, 40.4 per cent. were aged 20 to 24 years, and only $10 \cdot 2$ per cent. were aged 15 to 19 years. On the other hand, of the suspected sources, only $25 \cdot 2$ per cent. were aged 25 and over, 33.6 per cent. were aged 20 to 24 , and noo less than 41.1 per cent. were aged 15 to 19 years.

\section{HOMOSEXUALS}

Other data from St. Mary's Hospital have also indicated that homosexuals are found most frequently among those born in the United Kingdom, less commonly among immigrants, and least of all among West Indians (Willcox, 1966a), but nevertheless some homosexuals are found among the West Indians (Willcox, 1965b).

\section{Summary and conclusions}

1) Some figures relating to the net inward movement of immigrants are given and calculations have been made from the data obtained from the studies of the British Cooperative Clinical Group since 1952 of the numbers of different immigrant groups with gonorrhoea and with primary and secondary syphilis attending the venereal disease clinics of England and Wales.

2) In $1968,42 \cdot 2$ per cent. of gonococcal infections in males and 17.3 per cent. of those in females arose in immigrants. West Indians of both sexes have been throughout the most prominent immigrant group.

3) The overall figures for males with gonorrhoea fell between 1952 and 1955, in spite of an increase in cases in West Indians, and they then rose explosively, more than doubling by 1961 . This increase was caused mainly by immigrants, particularly West Indians, and less than one-third of it was accounted for by the home population. There 
was then a small fall between 1961 and 1966 which was due to a marked decrease in West Indians with gonorrhoea. The figures for other immigrants remained static during this time but in spite of the overall fall there was a noticeable increase in the numbers of cases in persons born in the United Kingdom. There has since been a substantial further rise and the peak is probably not yet in sight. This second rise differs from the previous one, in that more than three-quarters of it has been accounted for by infections in persons born in the United Kingdom.

4) The figures for gonorrhoea in females have shown a continued upward trend during all four periods. Between 1952 and 1955 it was slight and just under one-half was accounted for by cases in U.K.-born females. Between 1955 and 1961 the figures more than doubled and unlike the similar large increase in males less than onethird of which was attributable to the home population seven out of ten cases could be accounted for by U.K.-born females. During the third period 1961-1966 the rise was again slight, but it again became very considerable during 1967 and 1968, and from 1961 onwards more than eight out of ten cases were contributed by U.K.-born females.

5) In 1968, 35 per cent. of infections with primary and secondary syphilis in males and 20.3 per cent. in females occurred in immigrants. In 1966 the figures for infections in immigrant men and for the home population were practically equal, but in the 2-year period, 1967-1968, cases in U.K.born males rose and those in immigrants declined. In the period 1964-1966, Asians were the most prominent immigrant group but infections in Asians have since decreased and the chief contribution is now from Europeans with West Indians in second place.

6) Only a relatively small proportion of gonococcal infections are imported (4.3 per cent. in 1967), the proportion of cases of primary and secondary syphilis being significantly larger. In a study made in $1963,28.5$ per cent. of cases of primary and secondary syphilis were found to have been imported, but 43.8 per cent. of the imported cases were brought in by U.K.-born persons; only $2 \cdot 4$ per cent. were imported by West Indians.

7) Available data suggest that West Indian immigrants are not directly concerned with the general problem of gonorrhoea in teenagers, but local studies have nevertheless shown that $41 \cdot 1$ per cent. of the sources of their infections may be persons aged 15 to 19 years of age. Homosexuals are most frequently identified among U.K.-born patients and least frequently among West Indians.

8) The situation remains that immigrants, in relation to their total numbers in the community, continue to contribute a greater relative proportion of venereal infections than do members of the same age groups of the home population; but while immigrants were formerly responsible for the greater part of the increase in the numbers of cases of gonorrhoea in males this is no longer so and today it is undoubtedly the home population which is mainly concerned. This is partly because more immigrants have their families with them and because the numbers of incoming adults have been reduced or halted.

9) The numbers of cases of gonorrhoea in males have now increased to 88.3 per cent. of the immediate post-war peak incidence and the 1945 peak for females has already been exceeded. The credit balance of case reduction attributable to the impact of antibiotic therapy has thus been virtually dissipated.

Grateful acknowledgements are expressed to the Home Office for kindly providing statistics of immigration.

\section{References \\ British Cooperative Clinical Group (1960) Brit. F. vener. Dis., 36, 233 \\ - (1962) Iibd., 38, 1 \\ (1963a) Ibid., 39, 1 \\ - (1963b) Ibid., 39, 149 \\ - (1965a) Ibid., 41, 24 \\ - (1965b) Ibid., 41, 237 \\ - (1965c) Ibid., 41, 244 \\ (1965d) Ibid., 41, 251 \\ - (1965e) Ibid., 41, 30 \\ - (1967a) Ibid., 43, 25 \\ (1967b) Ibid., 43, 89 \\ - (1968a) Ibid., 44, 55 \\ - (1968b) Ibid., 44, 299 \\ (1968c) Ibid., 44, 167 \\ - (1968d) Ibid., 44, 307 \\ - (1970a) Ibid., 46, 62 \\ - (1970b) Ibid., 46, 69}

Marcussen, P. V. (1953) Amer. F. Syph., 37, 355

Ministry OF HEALTH (1968) Annual Report of the Chief Medical Officer. 'On the State of the Public Health'. Part II, Appendix C (see Brit. F. vener. Dis., 1970, 46, 76)

WILlCox, R. R. (1963) Brit. F. vener. Dis., 39, 214

- (1965a) Brit. F. clin. Pract., 19, 255

- (1965b) Practitioner, 195, 628

- (1966a) Brit. F. vener. Dis., 42, 225

- (1966b) In 'Immigration, Medical and Social Aspects: a Ciba Foundation Report', ed. G. E. W. Wolstenholme and M. O'Connor, p. 64. Churchill, London 
Jefreriss, F. J. G., and Naughten, E. M. (1966) Brit. F. vener. Dis., 42, 167.

\section{L'immigration et les maladies vénériennes en Angleterre et au Pays de Galles}

SOMMAIRE

(1) On indique quelques chiffres sur l'entrée dans le pays des immigrants ainsi que le résultat de calculs établis d'après les informations provenant des études du British Cooperative Clinical Group depuis 1952 sur les différents groupes d'immigrants fréquentant les cliniques vénéréologiques d'Angleterre et du Pays de Galles pour gonococcie et pour syphilis primaire et secondaire.

(2) En 1966, les immigrants représentaient $42,2 \%$ des infections gonococciques masculines et $17,3 \%$ des cas féminins. Partout, les Antillais des deux sexes étaient le groupe d'immigrants le plus représenté.

(3) Pour la gonococcie masculine, le nombre des cas diminua dans l'ensemble entre 1952 et 1955, malgré une augmentation chez les Antillais, mais, vers 1961, il augmenta d'une manière explosive, faisant plus que doubler. Cette augmentation fut principalement due aux immigrants, particulièrement les Antillais, et moins d'un tiers des cas fut rencontré dans la population nationale. Entre 1961 et 1966, on observa une faible baisse, du fait d'une diminution très nette des gonococcies chez les Antillais. Pour les autres immigrants, les chiffres restèrent stables pendant ce temps mais, malgré la chute générale, il y eut une augmentation notable du nombre de cas chez les sujets nés au Royaume-Uni. Depuis, il y eu une nouvelle augmentation importante et le sommet n'est probablement pas encore en vue. Cette seconde augmentation diffère de la précédente par le fait que les infections chez les sujets nés au Royaume-Uni comptent pour plus des trois-quarts.

(4) Pour la gonococcie féminine, on observe une tendance continue à l'augmentation pour les quatre périodes. Entre 1952 et 1955, celle ci fut légère et les cas notés chez les femmes nées au Royaume-Uni comptent pour un peu moins de la moitié. Entre 1955 et 1961, les chiffres ont plus que doublé et, contrairement à ce qui fut noté dans la même importante augmentation chez les hommes, moins d'un tiers des cas fut recontré dans la population nationale; les femmes nées au Royaume-Uni figurent pour 7 cas sur 10. Pendant la troisième période, 1961-1966, l'augmentation est restée légère mais elle devint de nouveau très considérable pendant 1967 et 1968 et, pour ces deux périodes, l'augmentation, pour plus de 8 cas sur 10, est notée chez des femmes nées au Royaume-Uni.
(5) En 1968, 35\% des cas de syphilis primaire et secondaire contagieuse chez les hommes et $20,3 \%$ chez les femmes furent notés chez les immigrants. En 1966, les chiffres des cas contagieux pour les hommes furent pratiquement les mêmes pour les immigrants et pour la population nationale; cependant, pour la période de 2 ans qui suivit, 1967-1968, le nombre des cas masculins augmenta chez les sujets nés au Royaume-Uni alors, que celui des cas observés chez les immigrants diminua. Pour la période 1964-66, le groupe prépondérant est représenté par les immigrants asiatiques mais, chez les Asiatiques, le nombre des cas contagieux a diminué depuis et ce sont les Européens, et les Antillais en deuxième place, qui occupent la position prépondérante.

(6) La proportion d'infections gonococciques importées $(4,3 \%$ en 1967) n'est que relativement faible alors que pour la syphilis primaire et secondaire la proportion est significativement plus élevée. En 1963, 28,5\% des cas de syphilis primaire et secondaire étaient importés, mais $43,8 \%$ de ces cas importés concernaient des sujets nés au Royaume-Uni; 2,4\% seulement furent importés par des Antillais.

(7) Les informations disponibles suggèrent que la gonococcie chez les moins de 20 ans ne concerne pas directement les immigrants antillais; cependant, des études localisées ont montré que, pour $41,1 \%$, leur infection pouvait être due à des personnes âgées de 15 à 19 ans.

Les homosexuels se reconnaissent plus fréquemment chez les malades nés au Royaume-Uni que chez les Antillais.

(8) Il n'en reste pas moins que les immigrants, compte tenu de leur nombre total dans la communauté, continuent à représenter une proportion relativement plus grande d'infections vénériennes que les sujets du même âge de la population nationale. Cependant, alors que les immigrants étaient auparavant responsables des cas de gonococcie masculine dans une forte proportion, ceci n'est plus vrai actuellement et, maintenant, c'est indubitablement la population nationale qui est principalement en cause. Ceci est partiellement dû au fait qu'un plus grand nombre d'immigrants ont leur famille avec eux et que les arrivées d'adultes au Royaume-Uni sont réduites ou arrêtées.

(9) Le nombre des cas de gonococcie masculine est maintenant arrivé à représenter $88,3 \%$ de l'incidence maximale observée juste après la guerre et, pour les femmes, le pic de 1945 est déjà dépassé. La favorable réduction des cas attribuables à l'introduction de l'antibiothérapie apparaît alors comme n'existant virtuellement plus. 